\title{
Pharmacological evaluation of Vrishya karma (Aphrodisiac activity) of Whole plant of Lavandula bipinnata (Roth) Kuntze
}

\author{
Research Article
}

\section{Narendra Singh Dhaked ${ }^{*}$, Mukesh B Nariya², Acharya R N³}

\author{
1. PG Scholar, 3. Professor and HOD, Dravyaguna Department, ITRA, Jamnagar. \\ 2. Head, Pharmacology Laboratory, ITRA, Jamnagar.
}

\begin{abstract}
Background: Lavandula bipinnata Roth. of family Lamiaceae known as Kamaraja in Odisha is an erect, strongly fragrant, annual herb with multifaceted ethno medicinal claims to treat, poisons, tooth ache, anxiety, depression, headache, cold and sexual disorder etc. Aim: To study the effect of whole plant of Lavandula bipinnata for its aphrodisiac activity in albino rats. Material Methods: The sexually active male rats were chosen separately and divided into 2 groups; each group consisting of 6 animals and the study was carried by using the suitable animal experimental model. The data generated during the study were analyzed by employing Student's ' $t$ ' test for paired and unpaired data as applicable to determine significant difference between groups at $P<0.05$. Results: Lavandula bipinnata showed significant increase in weight of rats in comparison with initial weight. Test drug provided significant increase in mounting frequency, licking, chasing, genital sniffing, in comparison to control group and nonsignificant increase in mounting latency and serum testosterone level. Conclusion: Lavandula bipinnata whole plant possess significant aphrodisiac activity in test rat model and confirms its traditional claim as an aphrodisiac.
\end{abstract}

Key Words: Aphrodisiac, Kamaraja, Lavandula bipinnata Roth., Vrishya.

\section{Introduction}

Aphrodisiacs are the substances which are used to increase sexual activity and help in fertility. The basic and fundamental purpose of sex and sexuality is the "continuation of progeny" and the survival of human race (1). Infertility and impotency are one of the major health issues now days in society and to deal with it is the need of the time (2). Many synthetic drugs are available and or used to treat the sexual problems. Being expensive and also their ability to provoke serious adverse effects are some of the drawback for these drugs. Hence, there is always a search of aphrodisiac drugs from plant origin. An ethno botanical information reports about potential of 200 plants as aphrodisiac (3).

Recent studies reports aphrodisiac study of certain drugs of Lamiaceae family such as Clinopodium gilliesii Benth.,(4) Lavandula angustifolia Linn.,(5) Occimum basilicum Linn.,(6) Occimum gratissimum Linn.,(7) Pogostemon bengholensis Burm.f.,(8) Pogostemon cablin Benth.,(9) Pogostemon ouricularius Linn.,(10) Salvia fruticosa Miller.,(11) Salvia pelbeia R.Br.,(12) Satureja khuzestanica Linn.,(13) Scutellaria

* Corresponding Author:

Narendra Singh Dhaked

PG Scholar,

Dravyaguna department,

ITRA,

Jamnagar. India

Email Id: narendradhaked05101991@gmail.com discolor Colebr.,(14) Sideritis syriaca Linn.,(15) Vitex agnus-castus Linn.,(16) etc.

Lavandula bipinnata Roth., of family Lamiaceae is an erect, strongly fragrant, annual herb preferably growing on rocky hill slopes. Commonly found in open areas especially hills surrounding the cities throughout India (17). Various parts like root, stem, leaf, fruit, flowers or whole plant, have been reported different disease conditions L. bipinnata reported for many pharmacological activity including analgesic, anticonvulsant, antidepressant, cholagogue, antispasmodic, digestive aid, antioxidant, antiinflammatory, cancer chemo preventative, insecticide or aphrodisiac (18).

The present study has been planned to assess the aphrodisiac activity of its whole plant on Wistar albino rats.

\section{Materials and Methods \\ Collection and authentication}

The plant Lavandula bipinnata (Roth.) Kuntze was identified by studying the morphological characters of various parts and comparing them with various characters described in flora and books (19-21) and was collected by the scholar from one of its natural habitats, Paikmal, Ghandmardhan hill, Odisha, during the month of December 2019, with the help of local Vaidya and taxonomist. Herbarium sheet of sample were deposited to institute pharmacognosy museum (voucher specimen NO. Phm/6301/2019-20) for future reference. 
Wistar Albino rats of either sex weighing between $200 \pm 40 \mathrm{~g}$ were used for experimental study. The animals were obtained from the Animal house attached to the Pharmacology laboratory. Animals were exposed to the $12 \mathrm{hrs}$ light and dark cycles with ideal laboratory condition in terms of ambient temperature $(23 \pm 3)$ and relative humidity $(50-60 \%)$. They were fed with standard rat pellet feed and drinking water given ad libitum. All the experimental protocols were carried out after obtaining permission from Institutional Animal Ethics Committee (IAEC/27/2020/16) as per guideline of CPCSEA, India.

\section{Selection of male rats}

The selected active male rats (weight between $200 \pm 40 \mathrm{~g}$ ) were kept separately for 10 days prior to study. They were trained for sexual experience with normal estrus female rats in estrus cycle. Male rats were again allowed to acclimatize to the new atmosphere in the transparent case, which was used as test area. It was of square structure made of fiberglass with opening at both upper and lower end.

\section{Selection of female rats}

Adult female rats of the weight between $200 \pm 40$ $\mathrm{g}$ were selected for the study. They were kept in group in separate cages after marking. To select the rats for the copulatory study, their vaginal smears were taken prior to experimentation and only estrus female were used for the present study.

\section{Test drugs}

The whole plant powder was grounded into fine powder by mechanical grinder and sieved (mesh no.120\#) and powder were kept in air tight glass jar for use in experimental study.

\section{Dose fixation}

Dose of the test drug was fixed by extrapolating the human dose to laboratory animals on the basis of body surface area ratio as per the table of Paget and Barnes (1964). (22) Human dose of Lavandula bipinnata whole plant powder- $3 \mathrm{~g} /$ day

- Rat dose = Therapeutic human dose X Body surface area ratio (convertibility factor) for rat

- = Human dose x 0.018 for rat weighing $200 \mathrm{~g}$

- = $3 \mathrm{~g} \mathrm{x} 0.018=54 \mathrm{mg} / 200 \mathrm{gm} \mathrm{rat}=270 \mathrm{mg} / \mathrm{kg}$ body weight of rat/day

\section{Route of administration}

The test drug was administered according to the body weight of the animals by oral route with the help of oral cannula.

\section{Experimental details}

The selected male rats were divided into two groups randomly comprised of six animals each as follows.

- Group I: Normal control group, received distilled water $(10 \mathrm{ml} / \mathrm{kg}, \mathrm{po})$

- Group II: Whole plant of Lavandula bipinnata (Roth.) (Whole plant powder of L. bipinnata) $(270 \mathrm{mg} / \mathrm{kg}$, po) respective groups for 30 consecutive days. On $30^{\text {th }}$ day, one hour after test drug administration, sexual behaviour of each male rat was observed visually in the transparent area with selected female estrus rats.

First, vaginal smear of female rats were taken to assess the estrus stage. Only estrus female rats were selected for the experimentation. The estrus female rat was placed into the transparent cage with individual male rat for 30 minutes under dim light with green curtains on the window and complete silent environment. Duration of sexual activities was recorded (time in seconds) with aid to stop watch. The following parameters were noted for aphrodisiac activity of test drugs,

1. Initiation of latency of sexual behaviour i.e. grooming of genitals, sniffing, licking etc.

2. Mounting latency, mounting frequency.

3. Average duration of sexual activity.

4. Sex hormone analysis

All the treated and control group animals were observed individually with fresh receptive female rats. Any noise and jerking movement of the mating area was avoided. Sufficient space for the animals in the mating area was provided to be enable them to chase each other in dim light. Cleaning of the mating area was done after each trial.

\section{Statistical analysis}

Result are presented as Mean \pm SEM, difference between the group was statistically determined by Student's ' $t$ ' test for paired and unpaired data for unpaired data to determine significant difference between group at $p<0.05$. The level of significance was noted and interpreted accordingly.

\section{Observations and Results \\ Body weight}

Table 1: Effect of $L$. bipinnata whole plant powder on body weight of albino rats

\begin{tabular}{|c|c|c|c|c|c|}
\hline \multirow{2}{*}{ Group } & \multicolumn{5}{|c|}{ Body weight (g) } \\
\cline { 2 - 7 } & Initial & $7^{\text {th }}$ day & $\mathbf{1 4}^{\text {th }}$ day & $2^{\text {st }}$ day & Final \\
\hline Control & $153.83 \pm$ & $159.00 \pm$ & $186.17 \pm$ & $207.83 \pm$ & $237.16 \pm$ \\
& 2.33 & 4.82 & $5.76^{*}$ & $7.46^{*}$ & $10.55^{*}$ \\
\hline L. & $236.60 \pm$ & $257.66 \pm$ & $271.17 \pm$ & $282.67 \pm$ & $290.66 \pm$ \\
bipinnata & 5.92 & $8.29^{* *}$ & $10.66^{*}$ & $10.66^{* *}$ & $11.30^{*}$ \\
\hline
\end{tabular}

Data: Mean \pm SEM

${ }^{*} \mathrm{P}<0.01, * * \mathrm{P}<0.001$ when compared to initial body weight (Paired ' $t$ ' test)

The data related to the effect of test drug on body weight in albino rats has been represented in table 1. An apparent gain in body weight was observed in test drug group including normal control group when the values compared with their respective initial weights. Control group showed statistically significant increase from $14^{\text {th }}$ day onwards and in test drug treated group i.e. L. bipinnata showed significant increase in weight gain 
of rats from $7^{\text {th }}$ days onwards compared with their respective initial weights.

\begin{tabular}{|c|c|c|c|c|}
\hline \multirow[b]{2}{*}{ Treatments } & \multicolumn{4}{|c|}{ Sexual behaviour activity of rats on $3^{\text {th }}$ day } \\
\hline & $\begin{array}{c}\text { Licking } \\
\text { (no.) }\end{array}$ & $\begin{array}{c}\text { Chasing } \\
\text { (no.) }\end{array}$ & $\begin{array}{l}\text { Genital } \\
\text { Sniff }\end{array}$ & $\begin{array}{l}\text { Mounting } \\
\text { frequency } \\
\text { (no) }\end{array}$ \\
\hline Control & $8.66 \pm 1.92$ & $5.66 \pm 1.35$ & $7.00 \pm 1.29$ & $0.33 \pm 0.21$ \\
\hline L. bipinnata & $\begin{array}{c}20.00 \\
\pm 1.98 @\end{array}$ & $\begin{array}{c}19.83 \\
\pm 2.75 @ @\end{array}$ & $\begin{array}{c}\text { 16.33 } \\
\pm 1.40 @ @\end{array}$ & $\begin{array}{c}11.00 \\
\pm 2.20^{*}\end{array}$ \\
\hline
\end{tabular}

Data: Mean \pm SEM

@ $\mathrm{P}<0.01$, @@ $<<0.001, * \mathrm{P}<0.001$, when compared to control group (Unpaired ' $\mathrm{t}$ ' test)

Data pertaining to the effect of L. bipinnata on sexual behaviour of male rats are summarized in table 2. L. bipinnata whole plant powder produced statistically significant increase in number of licking of female genital, chasing behind female rats, sniffing and mounting frequency like sexual behaviour activity in male rats in comparison to control group.

\begin{tabular}{|} 
Table 3: Effect of $\boldsymbol{L}$. bipinnata whole plant powder \\
on serum testosterone level in albino rat \\
\begin{tabular}{|c|c|c|c|}
\hline Treatments & $\begin{array}{c}\text { Dose } \\
\text { (per kg) }\end{array}$ & $\begin{array}{c}\text { Serum testosterone } \\
(\mathbf{n g} / \mathbf{m l})\end{array}$ & $\begin{array}{c}\% \\
\text { Change }\end{array}$ \\
\hline Control & -- & $133.36 \pm 42.49$ & -- \\
\hline L. bipinnata & $270 \mathrm{mg} / \mathrm{kg}$ & $213.56 \pm 50.36$ & $60.13 \uparrow$ \\
\hline
\end{tabular}
\end{tabular}

Data: MeanSEM; $\uparrow$ Increase

Table 3 shows the data related to the effect of test drugs on serum testosterone level in albino rats. The serum testosterone level was increased in rats treated with whole plant $L$. bipinnata powder in comparison to normal control group. Test drug produced effect in comparison to normal control group.

\section{Dicussion}

In India, indigenous remedies have been used in treatment of sexual dysfunction since the time of Charaka and Sushruta. An aphrodisiac is defined as an agent that arouses sexual desire. Sexual health and function are important determinants of quality of life. To overcome the problem of male sexual erectile dysfunction various Indian natural aphrodisiac plant potentials were preferred (23).

During the experimental study, in comparison to control group, there was significant increase (values) in body weight of albino rats in test drug group. Lavandula bipinnata possess phytochemicals i.e. alkaloids, carbohydrate, glycosides, saponin, phenol, tannin, gum and mucilage. Histochemicals result of $L$. bipinnata indicates presence of starch, protein, tannins, saponin, fats, alkaloids and glycosides (24). Among them some phytoconsituents carbohydrate and glycosides and fat are helpful in increasing body weight. These all factors can lead to weight gain in animal.

In mount frequency, L. bipinnata showed significant increase in comparison to control group.
Lamiaceae, also called as mint family, one of the largest families including herbs and shrubs often with aroma. Clinically not recorded an aphrodisiac activity in classical texts, L. bipinnata (Roth), contains different types of phyto-chemicals like Camphor, Lavandulol, Linalyl acetate and Lavandulol acetate. (25) Lavender essential oil derived from L. bipinnata is used in balm, perfumes, cosmetics and topical application. It is beneficial for anxiety, headaches depression and cold (26). Lavender is considered to be an aphrodisiac. The Lavender aroma and pumpkin dough caused the largest increase in blood flow to the penis (27). Camphor is used as an aphrodisiac to excite the reproductive organs, the effect of camphor on sexual performance might also be mediated via its effects on sympathetic nervous system, since an earlier report showed that camphor specifically inhibited catecholamine secretion by blocking nicotinic acetylcholine receptors (28). Libido is under psychosomatic, neurogenic, vascular and hormonal (primarily testosterone) controls (29).

In rest of the parameters the sexual behaviour i.e. licking, chasing and genital sniffing the drug treated group revealed significant effect when compared to control group. Tactile impulses enter the spinal cord from areas adjacent to the penis to aid in stimulating the sexual act. For instance, stimulation of the anal epithelium, the scrotum and perineal structures in general can send signals in to the cord that add to sexual sensation. Indeed one of the cause of sexual drive is filling of sexual organs with secretions. Appropriate physical stimuli can greatly enhance the ability of a person to perform the sexual act. Simply thinking sexual thought or even dreaming that the act of intercourse is being performed can initiate the male act, culminating in ejaculation. There are the factors related to male psyche which contribute to their sexual behaviour. These are attraction for women, war and defence territories etc (30). According to Ayurveda, the study was carried out in shishir ritu which comes under aadaana kaala, hemant and shishir are similar so the condition of dahabala in rats obviously to be high in amount and overall good aagneya bhav in prakruti and good libido and enjoy sexual intercourse up to full satisfaction at the advent of shishir(31). Vrishya karma would have caused the significant finding in test drug group.

In case of serum testosterone, non-significant increase in value was noted in case of Lavandula bipinnata (Roth) treated group but slightly increase the level of testosterone in comparison to control groups. The reproductive function of male can be divided into three major subdivision: spermatogenesis, performance of the male sexual act and regulation of male reproductive function by various hormones. Testosterone is also responsible for development of secondary sexual characteristics such as increase muscle and bone mass and the growth of body hairs. Anabolic effects exhibited by testosterone include growth of muscles and skeletal mass growth. Weight gain in control and vehicle control animal groups can be attributed to this (32). There are many references regarding fluctuation and huge variability in values of 
serum testosterone of rats during their circadian rhythm, seasonal cycle as well as during complete life cycle.(33)

The data generated during this study reveals presence of high aphrodisiac activity in L. bipinnata. and significantly increase androgenic activity in this research work at this particular dose level, dosage form and in this particular experimental animal model.

\section{Conclusion}

L. bipinnata whole plant powder showed significant increase in weight gain of rats, mounting frequency, licking, chasing, genital sniffing, nonsignificant increase in mounting latency, serum testosterone in experimental animals.

\section{Acknowledgements}

The authors are thankful to the Director and Staff of Pharmacology Laboratory, I.T.RA., Jamnagar for providing facilities to carry out the research work.

\section{Financial support and sponsorship}

As a part of $\mathrm{PG}$ thesis work

\section{Competing Interest}

Author have declared that no competing interest exist.

\section{Abbreviations Used}

SEM: standard error of mean, ANOVA: Analysis of variance, SI: Significant increase, NSI: Non significant increase.

\section{References}

1. Kothari P. common sexual problems. 3rd ed. New Delhi; UBS publishers; 2001. 1-6(155):203-204, $221 \mathrm{p}$.

2. Bhargava C. Effect of Bombax ceiba L. on Spermatogenesis, sexual behaviour and erectile function in male rats. Andrologia. 2012 May; 44 suppl 1: 47; 4-8

3. Ramandeep Singh, Ashraf Ali, Sarabjeet Singh, current Status of Indian Medicinal Plants with aphrodisiac potential. Pharmacologia.2013; Vol 4; 276-284

4. Hnatyszyn $\mathrm{O}$ et.al, Argentinian plant extracts with relaxant effect on the smooth muscle of the carpus cavernosum of guinea pig. Phytomedicine; 2003:10; 669-674p.

5. Hirsch A, Gruss J. Human male sexual response to olfactory stimuli. J Neurol Orthop Med Surg. 1999; $19 ; 14-19$

6. Khojasteh SBM et.al, A Review on medicinal plant used for Improvement of Spermatogenesis. Biol Med; (Aligarh) 8; 292

7. Ramandeep Singh et al, some medicinal plant with aphrodisiac potential. A current status. Journal of Acute Disease. 2013; 179-188

8. Ashwini SV, Amol KB, Basawaraj HC, Shrishail GM. A Comprehensive Review on Pogostemon benghalensis (Burm. F.) O. Kuntze. Research and
Reviews. Journal of Pharmacognosy and Phytochemistry. 2013; 1(1); 10- 15

9. Bunrathep $\mathrm{S}$ et.al, Chemical consitituents from leaves and cell cultures of Pogostemon cablin and use of precursor feeding to improve patchouli alcohol level. J Sci Asia. 2006; 32; 293-296

10. Chakrapani P, Venkatesh K, Singh CSB, Jyothi AB, Kumar P, Amareshwari P, Rani AR. Phytochemical, Pharmacological importance of Patchouli [Pogostemon cablin (Blanco) Benth] an aromatic medicinal plant. Int. J. Pharm. Sci. Rev. Res., 2013; 21(2); 7-15

11. Giuliani C, Maleci Bini L, Insight into the structure and chemistry of glandular trichomes of Labiate, with emphasis on subfamily Lamioideae. Plant systematics and evolution. 2008; vol. 276, no.3-4; 199-208

12. Mathur M, Sundaramoorthy S, Plant with aphrodisiac potentials-The knowledge and the gaps. In: Indian Medicinal Plants (ed.) Trivedi. P.C. Aavishkar Publishers; Jaipur, India: 2009. 1-31p.

13. Haeri S, Minaie B, Amin G, Nikfar S, Khorasani R, Esmaily H, et al. Effect of Satureja khuzestanica essential oil on male rat fertility. Fitoterapia. 2006; 77; 495-496

14. Burkill IH, A Dictionary of Economic product of Malay Peninsula. Govt of the Straits Settlement, London; 2003.

15. Hayta S, Polat R, Selvi S. Traditional uses of medicinal plants in Elazig (Turkey). Journal Ethnopharmacol. 2014; 3; 613-623

16. Bremer B, Bremer K, Chase M W et al., An update of the Angiosperm Phylogeny Group classification for the order and families of flowering plants. APG $\Pi$, Botanical Journal of the Linnean Society, Vol 141, no. 4: 2003; 399-436p.

17. https://sites.google.com/site/efloraofindia/species/ a---1/1/lamiaceae/lavandula/lavandula-bipinnata dated 8-7-2021 time 13.04 IST

18. Catherine J, Chu and Kathi J. Kemper, Lavender (Lavandula spp.) Lavender, Longwood Herbal Task Force: 2001

19. Saxena H O, Brahman M. The Flora of Orissa. Vol 3, Regional Research Laboratory \& Orissa Forest Development Corporation Ltd.: Printed at Capuial Business Service \& Consultancy, Bhubaneshwar; April 1994; 1452-1453p.

20. Gaikwad SP, Gore RD \& Garad KU, Additions to the flora of Marathwada region of Maharashtra, India. Journal of Threatened Taxa. April, 2012; 4(4); 2515-2523

21. Bole PV, Pathak JM, Flora of Saurashtra part 2. Printed by botanical survey of India; 1988. 216p.

22. Paget GE, Barns JM. Evaluation of drug activities. In: Lawrence, D.R. and Bacharach AL Pharmacometrics. Academic press, New York. 1964; 1:161p.

23. Ramandeep Singh, Ashraf Ali, Sarabjeet Singh, current Status of Indian Medicinal Plants with aphrodisiac potential. Pharmacologia. 2013; Vol 4; 276-284 
24. Vidya V. Shinde, S.R. Kshirsagar, World Journal of Pharmaceutical Research. 3(3); 4217-4223

25. 25. Rama Rao V, Shiddamallayya N, Diversity and therapeutic potentiality of the family Lamiaceae in Karnataka State, India: An overview. Species. 2015; 13 (37); 6-14

26. Rama Rao V, Shiddamallayya N, Kavya N Kavya B, Venkateshwarlu G et.al diversity and therapeutic potentiality of family Lamiaceae in Karnataka state, India, International Journal for Species. ISSN; 2319-5746

27. Hirsch A, Gruss J. Human male sexual response to olfactory stimuli. J Neurol Orthop Med Surg. 1999; $19 ; 14-19$

28. Park TJ, Seo HK, Kang BJ, Kim KT. Noncompetitive inhibition by camphor of nicotine acetylcholine receptors. Biochem Pharmacol. 2000; $61 ; 787-93$
29. Waller DP, Kilinger JM, Zaneveld LJD. Physiology and toxicology of the male reproductive tract, In: Thomas JA, Korach KS, Mclachlan JA (editors). Endocrime toxicology, New York: Raven Press; 1985.

30. Chaudhary SK. concise medical physiology. Kolkata; New central book agency; reprint 2011. $328 \mathrm{p}$.

31. Charaka. Charaka Samhita. Jadavji Trikamji, Editor. Sutrasthana 6/17. Varanasi; Chaukhambha Orientalia Academy; Reprinted; 2011.

32. Ibidem (8) concise medical physiology.329p.

33. Heywood LH, Testosterone levels in the male laboratory rat. Variation under experimental conditions. International Journal of Andrology. $1980 ; 3 ; 519-529$. 